\title{
Single wall carbon nanotubes growth over cobalt-iron mesoporous MCM-41 bimetallic catalyst under methane chemical vapor deposition, an experimental and DFT evaluation
}

\author{
Frank Ramírez-Rodríguez ${ }^{1, *}$, Betty López ${ }^{1}$
}

\author{
Edited by \\ Juan Carlos Salcedo-Reyes \\ (salcedo.juan@javeriana.edu.co) \\ 1. University of Antioquia, Grupo \\ Ciencia de los Materiales, Medellín, \\ Colombia \\ *frank.ramirez@udea.edu.co \\ Received: $13-05-2019$ \\ Accepted: $13-05-2020$ \\ Published on line: 23-07-2020 \\ Citation: Ramírez-Rodríguez \\ F, López B. Single wall carbon \\ nanotubes growth over cobalt-iron \\ mesoporous MCM-41 bimetallic \\ catalyst under methane chemical \\ vapor deposition, an experimental \\ and DFT evaluation, Universitas \\ Scientiarum, 25 (2): 227-246, 2020. \\ doi: 10.11144/Javeriana.SC25-2.swen \\ Funding: \\ N.A. \\ Electronic supplementary \\ material: \\ N.A. \\ OPEN ACCESS
}

\begin{abstract}
Cobalt and iron MCM-41 catalysts were synthesized through an in-situ incorporation process starting from commercial iron and cobalt nitrates. The incorporation was confirmed by diffuse reflectance UV spectroscopy (DRS-UV) inspecting the cobalt and iron silicate-like photon absorption features and comparing with pure MCM-41-Co and MCM-41-Fe catalysts. Additionally it was found that the incorporation of cobalt and iron does not compromise the mesoporous structure of MCM-41 as confirmed by $\mathrm{N}_{2}$ adsorption isotherms. All catalysts showed high surface areas $\left(\sim 1100 \mathrm{~m}^{2} \mathrm{~g}^{-1}\right)$. Catalysts performance was conducted in a simple methane chemical vapor deposition (CVD) set up at $800^{\circ} \mathrm{C}$ to produce single wall carbon nanotubes (SWCNT) under a constant flow of methane for $30 \mathrm{~min}$. CVD products were characterized by thermogravimetric analysis (TGA) and Raman spectroscopy, finding that the iron content in the catalysts favors the selectivity and yield of graphitic-like structures, and confirming the presence of SWCNT by the appearance of a characteristic radial breathing mode (RBM) signals. These results were supported by Density Functional Theory (DFT) simulations of the methane dissociation $\left(\mathrm{CH}_{4}+\mathrm{TM} \rightarrow \mathrm{H}_{3} \mathrm{C}-\mathrm{TMH}\right)$ over $\mathrm{Co}_{n}(n=1-5)$ and $\mathrm{Co}_{m} \mathrm{Fe}(m=1-4)$, finding a different activation energy trend where $\mathrm{Co}_{m} \mathrm{Fe}$ $(m=1-4)$ clusters have the lower activation energy. The DFT study also revealed a charge difference $\left(\delta_{C}-\delta_{\mathrm{TM}}\right)$ higher in the case of dissociation over $\mathrm{Co}_{m} \mathrm{Fe}(m=1-4)$ which may lead to an electrostatic stabilization of the transition metal, diminishing the activation energy of those clusters and leading to a faster carbon uptake.
\end{abstract}

Keywords: DFT; Raman; SWCNT; UV-Vis.

\section{Introduction}

Single wall carbon nanotubes (SWCNT) are one of the most exceptional carbon materials, their singular chemical and physical properties rely on their graphitic structure [1, 2], which is characterized by a $\pi$-delocalized electron density that confers a special reactivity, like an aromatic compound, and that is easily chemically modifiable with heteroatoms or organic functional 
groups. These properties turn them into a potential material with the capability to form covalent composites with polymers for physical-enhanced strength applications $[3,4,5]$. Some other applications take advantage of the semiconducting behavior and high electron mobilities [6] to increase charge transport in polymer solar cells [7], even in inorganic solar cells [8], and also field effect transistors $[9,10]$. SWCNT are quite expensive to produce due to the high energy processes required, and that the most used carbon source, carbon monoxide, is extremely toxic. Methane is a cheap and non-toxic carbon source and it has proven to be a suitable carbon source for growing selectively SWCNT with certain transition metals [11]. Cobalt metal is one of the most studied for SWCNT growth due to a high activity towards SWCNT $[12,13]$. Iron catalysts also have proven to be very effective for MWCNT growth [14] but also active towards SWCNT [15]. Some works have been conducted where bimetallic catalysts are used instead of single metal catalysts; those systems proved to be suitable for growing CNT structures in high yield by metal particle stabilization within a template [16], avoiding a sintering process, and metal particles are able to attain small sizes where SWCNT can grow [17]. Iron and cobalt bimetallic catalysts have been used to grow MWCNT [18], nevertheless, as far as we know there is no evidence of SWCNT synthesis over cobalt and iron catalysts using methane as carbon source. In this work cobalt and iron bimetallic MCM-41 catalysts were prepared by means of an in-situ incorporation process, and tested in a regular CVD set up to assess the effect of iron on the selectivity and yield towards SWCNT. Density functional theory based kinetic simulations were also performed to support the experimental findings.

\section{Materials and methods}

\section{Materials}

Tetramethylammonium silicate $\left(\mathrm{TMASiO}_{2}\right)$ (15\%-20\%) from Sigma-Aldrich, colloidal silica Cab-O-Sil (99.5\%) from Sigma-Aldrich, $\left[\mathrm{Co}\left(\mathrm{NO}_{3}\right)_{2} \cdot 6 \mathrm{H}_{2} \mathrm{O}\right]$ (99.3\%) from Merck, $\left[\mathrm{Fe}\left(\mathrm{NO}_{3}\right)_{2} \cdot 9 \mathrm{H}_{2} \mathrm{O}\right]$ (99\%) from Merck, cetyltrimethylammonium bromide (99\%) (CTABr) from Sigma-Aldrich, Ambersep $900^{\circledR}$ from Alfa-Aesar, glacial acetic acid from Merck, and ammonia (27\% w/v) from Merck.

\section{Catalysts synthesis}

MCM-41 based catalysts were prepared following procedures previously reported [19] varying the iron content from $0.25 \%$ to $1.0 \%$ while the cobalt content is fixed at $2.0 \%$. In a typical procedure $1.25 \mathrm{~g}$ of colloidal silica Cab-O-Sil and $5.0 \mathrm{~g}$ of $\mathrm{TMASiO}_{2}$ are mixed with $25 \mathrm{~mL}$ of deionized water 
under magnetic stirring for $30 \mathrm{~min}$, then, $176 \mathrm{mg}$ of $\mathrm{Co}\left(\mathrm{NO}_{3}\right)_{3} \cdot 6 \mathrm{H}_{2} \mathrm{O}$ and $31.7 \mathrm{mg}$ of $\mathrm{Fe}\left(\mathrm{NO}_{3}\right)_{3} \cdot 9 \mathrm{H}_{2} \mathrm{O}$ are used to attain a load of $2.0 \%$ (cobalt) and $0.25 \%$ (iron). The mixture is stirred for further $30 \mathrm{~min}$, then $14.4 \mathrm{~g}$ of $\mathrm{CMTAOH}$ is added in a single portion and stirred for $30 \mathrm{~min}$ followed by $\mathrm{pH}$ adjustment to 11.5 with either acetic acid or ammonia solution. The prepared gel is thermally treated at $100^{\circ} \mathrm{C}$ for 3 days in autoclave and then filtered, dried at $80^{\circ} \mathrm{C}$ overnight, and calcined under air at $540^{\circ} \mathrm{C}$ to remove the surfactant. Pure iron and cobalt MCM-41 catalysts were prepared for comparison, following the same procedure as stated before with a nominal metal load of $2 \%$.

\section{Catalysts performance}

SWCNT synthesis was conducted in a vertical oven containing a quartz tube with an inner fritted quartz disc where the catalyst is placed during the synthesis. In a typical procedure, $200 \mathrm{mg}$ of catalyst is deposited over the fritted disc and a flux of $20^{\circ} \mathrm{C} \mathrm{min}^{-1}$ of nitrogen is passed over the catalyst until the oven reaches $700^{\circ} \mathrm{C}$, once this temperature is reached the nitrogen is switched to a reducing atmosphere $\left(\mathrm{N}_{2}: \mathrm{H}_{2}, 150 \mathrm{~cm}^{3} \mathrm{~min}^{-1}: 50 \mathrm{~cm}^{3} \mathrm{~min}^{-1}\right)$ for $30 \mathrm{~min}$ to partially reduce the metal cations into metal particles, followed by the rapid heating to $800^{\circ} \mathrm{C}$ under $\mathrm{N}_{2}$, and immediately switched to $200 \mathrm{~cm}^{3} \mathrm{~min}^{-1}$ of methane for $30 \mathrm{~min}$. Once the synthesis is finished the oven is cooled to room temperature under a flux of nitrogen.

\section{Computational details}

The reaction kinetics was studied quantum mechanically using the ORCA package [20]. To determine rate constants, small clusters with different atom amounts and varied composition were studied, namely $\mathrm{Co}_{n}(n=1-5)$, and $\mathrm{Co}_{m} \mathrm{Fe}(m=0-4)$. For each cobalt cluster and cobalt-iron cluster a relaxed potential energy surface (PES) scan for the methane single hydrogen transfer from the methane to the metallic cluster $\left(\mathrm{CH}_{3}-\mathrm{H}+\mathrm{Co}_{n} \rightarrow \mathrm{CH}_{3}-\mathrm{Co}_{n} \mathrm{H}\right.$, $\mathrm{CH}_{3}-\mathrm{H}+\mathrm{Co}_{m} \mathrm{Fe} \rightarrow \mathrm{Co}_{m} \mathrm{FeH}$ ) was made. The highest point in the reaction coordinate is further refined to obtain the transition state (TS) of the reaction, the activation energy (AE) of the reaction, and the reaction rate, that is determined via equations (1) and (2), where $G$ is the free energy thermally corrected at different temperatures:

$$
\begin{aligned}
\Delta G^{\neq} & =G_{T S}-G_{R}, \\
\ln \left(k_{R}\right) & =\ln \left(\frac{k_{B} T}{h}\right)-\frac{\Delta G^{\neq}}{R T} .
\end{aligned}
$$


All simulations used the Valence triple- $\zeta$ basis set Def2-TZVP [21] for non-transition metal elements, and Stuttgart-Dresden [22] (SDD) for cobalt and iron, the Perdew-Burke-Ernzerhof (PBEO) [23] functional was selected (see Fig. 1 for method selection) and molecular structures visualization and drawings were obtained with the Chemcraft software.

\section{Catalysts characterization}

Catalysts prepared were characterized by nitrogen adsorption isotherms in a ASAP 2020 Micromeritic at normal boiling point of nitrogen $(77 \mathrm{~K})$, to determine the mesoporous surface area with the Brunauer-Emmett-Teller (BET) [24] model and pore size distribution with the Barrett-Joyner-Halenda (BJH) model [25]. DRS-UV experiments were conducted in a Perkin Elmer Lambda $35 \mathrm{UV}-V$ is spectrometer with an integration sphere from $900 \mathrm{~nm}$ to $350 \mathrm{~nm}$, spectral features in this range were analyzed to determine whether the catalyst are incorporated or not.

\section{CVD products characterization}

Total carbon content was determined by means of thermogravimetric experiments in a TGA Q500 Thermal Advantage in oxidant atmosphere $\left(80 \% \mathrm{~N}_{2}\right.$ and $\left.20 \% \mathrm{O}_{2}\right)$ at heating rate of $20^{\circ} \mathrm{C} \mathrm{min}^{-1}$, Raman spectroscopy analysis of CVD products were conducted in a Horiba LabRam HR at $732 \mathrm{~nm}$ excitation wavelength, a single spectrum was collected for each sample under laser irradiation for $10 \mathrm{~s}$.

\section{Results}

\section{Catalysts characterization}

A typical IV nitrogen adsorption isotherm related to a non-interconnected mesoporous is observed for all samples, see Fig. 1A, with capillary condensation step from $0.3 P / P_{0}$ to $0.4 P / P_{0}$ [26]. That capillary condensation shape arises from the gas adsorption of a mesoporous, since all samples depict the same adsorption features their structural pattern are most-likely similar [27]. A quantitative measure of the porous quality is extracted by computing the maximum capillary condensation slope (calculated as $\Delta$ Volume $/ \Delta\left[P / P_{0}\right]$ ), see Table 1 (MCM-41-Fe and MCM-41-Co slopes for comparison), where higher slope values are related to a fine structural rearrangement. The slope value among the bimetallic catalyst is inversely related to the iron content, contrasting these values with the ones of the monometallic catalysts it is clear that iron inside the silica framework is inducing the largest porous structure disruption. That behavior may 
A

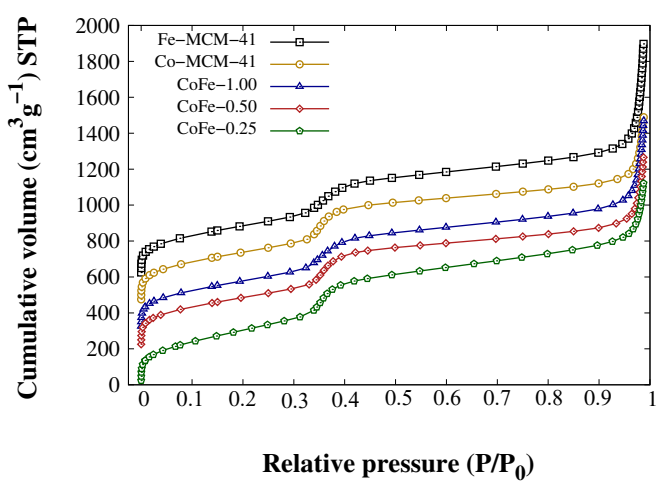

B

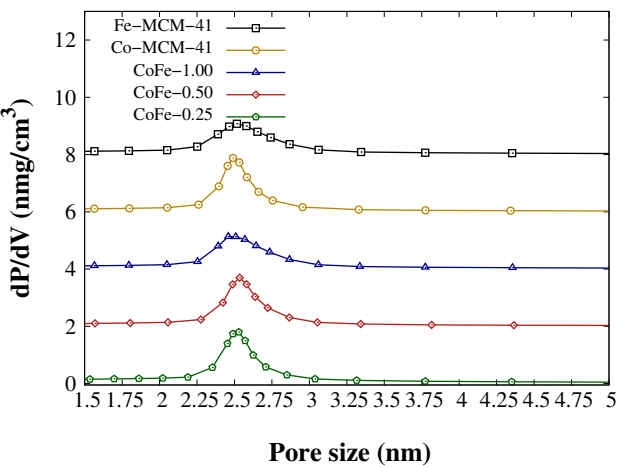

Figure 1. Nitrogen adsorption isotherms (A), and $\mathrm{BJH}$ pore size distribution of CoFe catalysts arranged by offset (B); MCM-41-Co and MCM-41-Fe are shown for comparison.

be attributed to the fact that $\mathrm{Fe}^{3+}$ in a silicate-like structure can attain a coordination number of 6 while $\mathrm{Co}^{2+}$ a coordination number of 4 . A main difference between them is that the former may induce more structural distortion since more $\mathrm{SiO}^{-}$are needed to stabilize the $\mathrm{Fe}^{3+}$ deviating from the ideal tetrahedral coordination in the MCM-41 structure.

Pore size distribution in Fig. 1B, shows a decrease in the intensity as the iron content increases reaching a minimum of intensity comparable to MCM-41-Fe. On the other hand, there is no significant difference in the average pore size but the FWHM (full width at half maximum) values, in Table 1, increase with iron content. This trend confirms that the iron incorporation leads to a largest siloxane network disruption since a larger FWHM means a wider pore size range. The variation in the catalysts is the iron content so the distortion may be attributed to iron and not to the presence of cobalt. Surface areas of MCM-41 catalysts, given in Table ??, are within the range $1080 \mathrm{~m}^{2} \mathrm{~g}^{-1}-1200 \mathrm{~m}^{2} \mathrm{~g}^{-1}$; this value is in good agreement for MCM-41 mesoporous silicas [28] which is actually desired since metal particle dispersion plays an important role to grow selectively SWCNT by suppressing metal particles sintering [29].

UV-Vis features of solid catalysts give information regarding the chemical environment of active transition metal cations, particularly in this report, iron, and cobalt species present features with poor overlapping which lead to a discrimination of whether cobalt and iron are being absorbed simultaneously. 
Table 1. Nitrogen adsorption results summary. a Total surface area (BET model).

${ }^{b} \mathrm{BJH}$ pore size mean diameter. ${ }^{c}$ Full Width at Half Maximum of the BJH distribution.

Catalyst $\mathrm{SA}^{\mathrm{a}}\left(\mathrm{m}^{2} \mathrm{~g}^{-1}\right) \quad \mathrm{DP}^{\mathrm{b}}(\mathrm{nm}) \quad \mathrm{FWHM}^{\mathrm{c}}(\mathrm{nm})$ Slope $\left(\mathrm{cm}^{3} \mathrm{~g}^{-1}\right)$

\begin{tabular}{|lllll|}
\hline Co & 1104 & 2.49 & 0.26 & 4042 \\
\hline $\mathrm{Fe}$ & 1100 & 2.52 & 0.48 & 2422 \\
\hline $\mathrm{CoFe}-0.25$ & 1202 & 2.53 & 0.28 & 3959 \\
\hline CoFe-0.50 & 1063 & 2.53 & 0.30 & 3722 \\
\hline CoFe-1.00 & 1081 & 2.51 & 0.44 & 2512 \\
\hline
\end{tabular}

Cobalt spectral features typically go from $550 \mathrm{~nm}$ to $700 \mathrm{~nm}$ when $\mathrm{Co}^{2+}$ is located into tetrahedral holes [30, 27], while iron incorporated in a silica-like material absorbs with an intensity maximum close to $400 \mathrm{~nm}$ [31]. The comparison of the spectral features of bimetallic catalysts with those of the single metal catalysts reveal that bimetallic catalysts share the absorption bands of both cobalt and iron. This suggest that both metals were successfully incorporated, besides, the peak related to iron increases as the nominal amount of iron increases, which means that the incorporation amount is higher for larger amount of iron during the catalyst synthesis. Through UV-Vis and nitrogen adsorption results it is feasible to confirm that the incorporation of metals have been achieved, and then those catalysts are suitable for SWCNT growth.

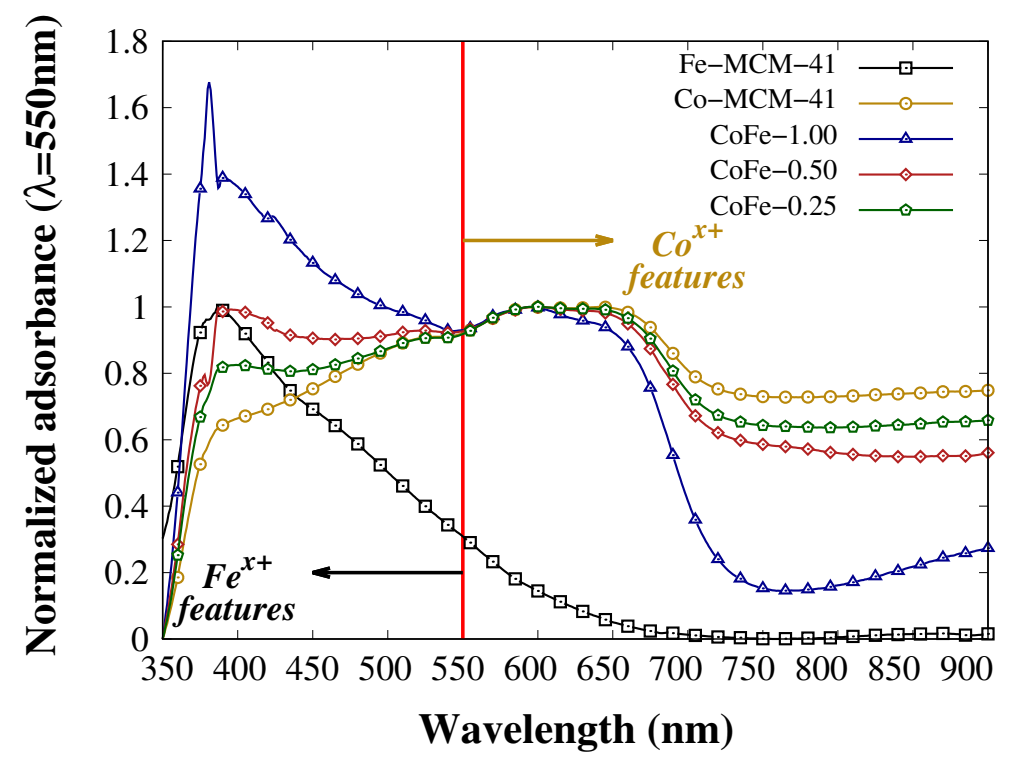

Figure 2. Diffuse reflectance UV-Vis (DRS-UV) of bimetallic catalysts $\mathrm{CoFe}$ and for comparison, MCM-41-Co and MCM-41-Fe spectra. 


\section{Catalysts performance}

Once the bimetallic catalysts have been prepared the SWCNT preparation is carried on, a first insight into the catalytic performance is conducted by means of thermogravimetric analysis under oxidant atmosphere to determine the total amount of carbon species deposited after the CVD procedure, see Fig. 3. Highly graphitic carbon species decompose over $500^{\circ} \mathrm{C}$ while non-graphitic species usually decomposes below $500^{\circ} \mathrm{C}$ [32]; within the graphics, there are no signs of appreciable weight loss related to non-graphitic species leaving only the event regarding the decomposition of graphitic-like species, and giving the $\pi$-aromatic nature of SWCNT. These results are good evidence of nanotubes formation, which will be confirmed later in this study.

Raman spectroscopy offers a better understanding regarding the nature of the carbon species growth during the CVD process and three features are expected if SWCNT are present in the sample. First, a radial breathing mode (RBM) $\left(150 \mathrm{~cm}^{-1}-400 \mathrm{~cm}^{-1}\right)$ related to the concentric movements of the tube, since SWCNT are the only species active in that region the occurrence of these signals is a conclusive evidence of SWCNT formation; also, the peak maximum within that range is inversely related to the tube diameter $d_{t}$ which is a valuable tool to determine the tube diameter distribution equation 3 :

$$
d_{t}=\frac{\omega_{\mathrm{RBM}}-10}{234} .
$$

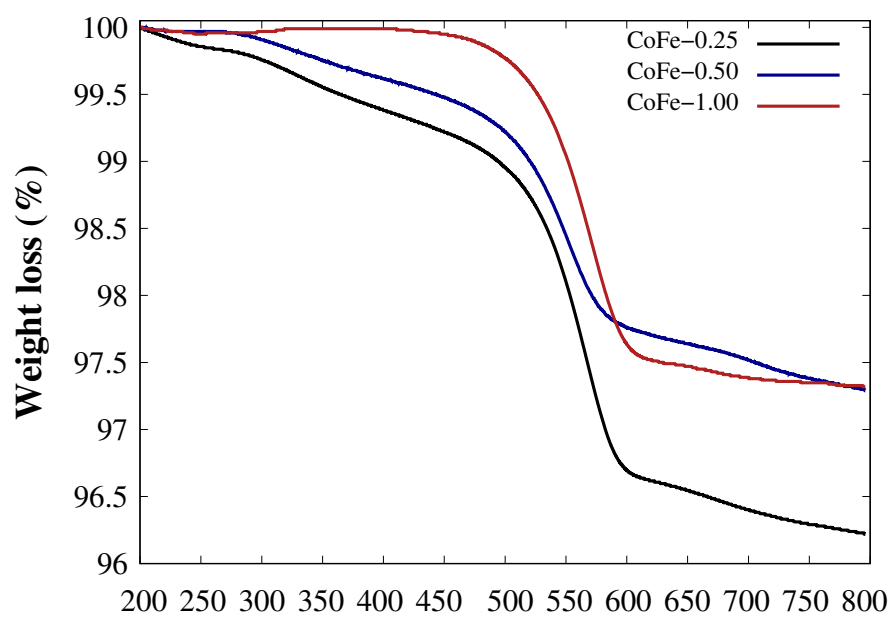

Tempearature $\left({ }^{\circ} \mathrm{C}\right)$

Figure 3. TGA profiles of CVD deposition over $\mathrm{CoFe}$ catalysts without purification. 
Second, a G-band $\left(\sim 1550 \mathrm{~cm}^{-1}\right)$ related to the tangential phononic mode of the carbon atoms within the graphitic structure. And third, a D-band $\left(\sim 1350 \mathrm{~cm}^{-1}\right)$, that arises from the broken hexagonal symmetry such as amorphous carbon and five-membered to seven-membered fused rings (Fig. 4). The area ratio of the G- and the D-bands give an insight about the quality of the graphitic-like material, the larger the ratio the higher the graphitic quality [34].

Carbon depositions over bimetallic catalysts show the aforementioned features with conclusive information of SWCNT formation. The G/D ratio found after signal integration gave ratios of: 1.15, 3.5, and 3.56 for CoFe-0.25, $\mathrm{CoFe}-0.50$, and CoFe-1.00 respectively, thus, the structural quality of the SWCNT increases as the iron content increases. These findings altogether with TGA results suggest that presence of iron in the samples is a key factor since the selectivity towards graphitic species and the total amount of carbon is proportional to the iron content, thus, a synergistic effect may be present between cobalt and iron.

An estimation of the tube diameter distribution is performed (deconvolution of the RBM signals with Gaussian functions) where each peak corresponds to a specific tube diameter and the relative population to the peak area weighted by the total RBM zone area, Table 2. In Fig. 5, the spectral deconvolution is depicted where a good fitting is attained. From these results,

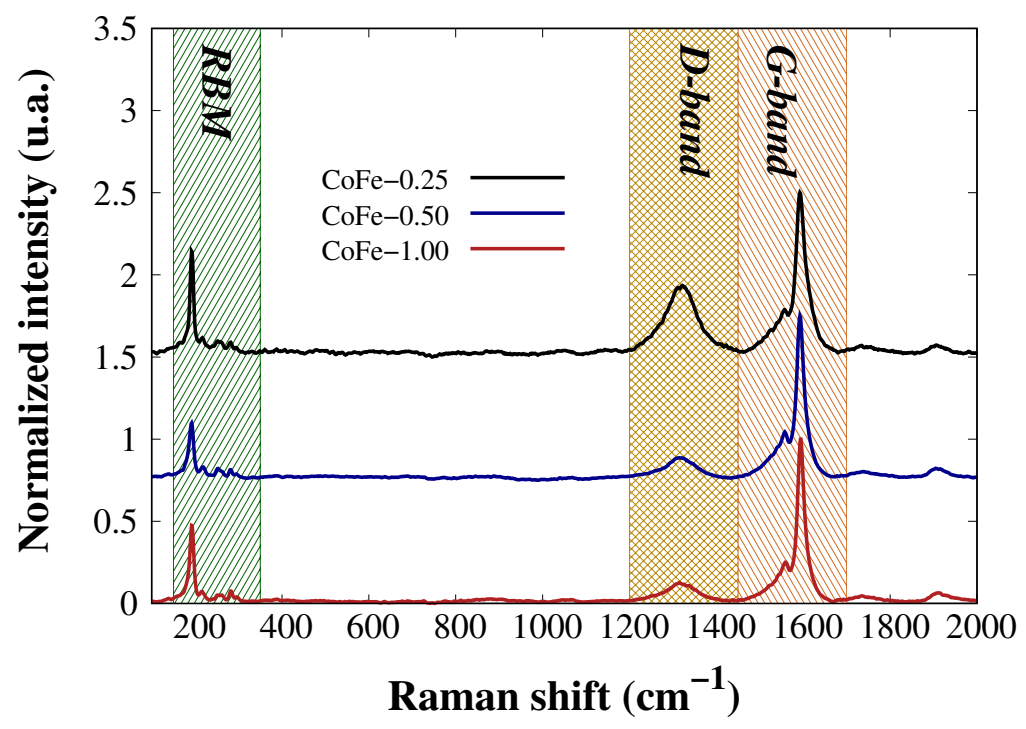

Figure 4. Full Raman spectra of CVD deposition over CoFe catalysts showing the main features. 
Table 2. RBM deconvolution results, estimated tube diameter population (\%) and tube diameter $\left(d_{t}\right)$.

\begin{tabular}{cccccc}
\hline \multicolumn{2}{c}{ CoFe-0.25 } & \multicolumn{2}{c}{ CoFe-0.50 } & \multicolumn{2}{c}{ CoFe-1.00 } \\
$d_{t}(\mathrm{~nm})$ & $(\%)$ & $d_{t}(\mathrm{~nm})$ & $(\%)$ & $d_{t}(\mathrm{~nm})$ & $(\%)$ \\
\hline 1.35 & 21.6 & 1.36 & 15.1 & 1.25 & 16.8 \\
\hline 1.18 & 52.5 & 1.21 & 29.8 & 1.18 & 63.9 \\
\hline 1.04 & 6.02 & 1.18 & 31.4 & 1.05 & 3.64 \\
\hline 0.9 & 11.84 & 1.04 & 7.12 & 0.90 & 3.40 \\
\hline 0.87 & 1.51 & 0.90 & 6.51 & 0.87 & 3.41 \\
\hline 0.81 & 5.18 & 0.87 & 3.22 & 0.81 & 6.90 \\
\hline 0.77 & 1.33 & 0.81 & 5.17 & 0.77 & 1.81 \\
\hline
\end{tabular}

the SWCNT tube diameter falls within the range $0.70 \mathrm{~nm}-1.40 \mathrm{~nm}$ regardless the catalyst composition, more than $70 \%$ of tube diameter contribution is within the range $1.0 \mathrm{~nm}-1.4 \mathrm{~nm}$ meaning a narrow diameter distribution. Experimentally, tube diameter is mostly dependent on the metallic particle size. The MCM-41 structure serves as a metal particle size control by

A

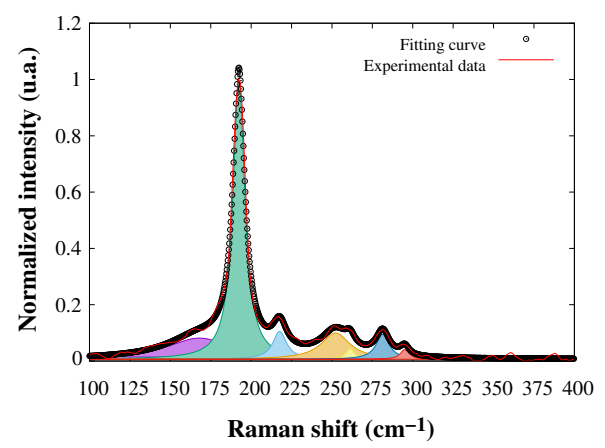

C

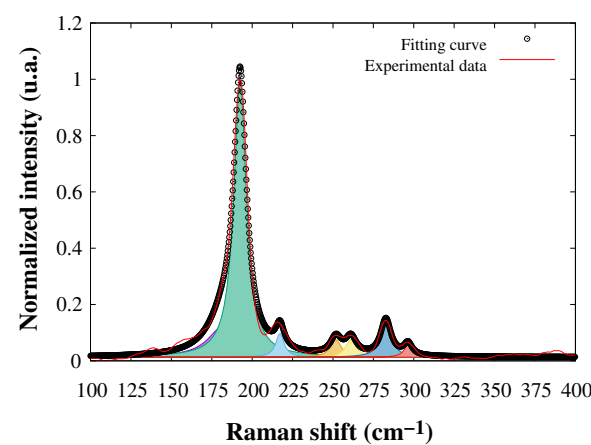

B

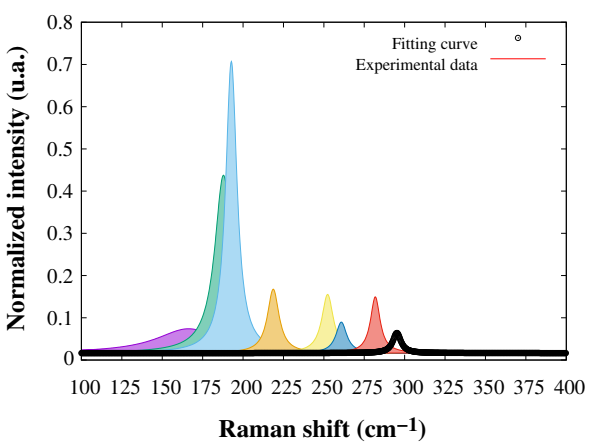

Figure 5. RBM section of CVD depositions over (A) CoFe-0.25, (B) CoFe-0.50, and (C) CoFe-1.00 catalysts. Experimental data and Gaussian deconvolution of most important peaks are depicted. 
confining the particles inside the pores, avoiding the sintering process after thermal reduction of iron and cobalt cations. Since the SWCNT diameter is mostly dependent on the particle size and all the catalysts showed the same average size, that size is expected to be similar to the SWCNT diameter [13, $35]$.

\section{Computational simulations.}

From TGA and Raman characterization it is clear that iron has an important role, but, with the techniques used in this study, it is not possible to determine how that behavior is related to the iron content, therefore, a computational study based on the density functional theory (DFT) methodology was performed. The activation energy (AE) and the reaction rate of the $\mathrm{CH}_{3}-\mathrm{H}$ bond dissociation over $\mathrm{Co}_{n}$ and $\mathrm{Co}_{m} \mathrm{Fe}$ clusters were calculated using the equations (2) and (3), but first, a potential energy surface (PES) scan was conducted starting from reactant $\left(\mathrm{CH}_{4}-\mathrm{Co}\right)$, passing through the transition state (TS), and finally getting the product $\left(\mathrm{H}_{3} \mathrm{C}-\mathrm{Metal}-\mathrm{H}\right)$. The maximum within the plot in Fig. 6 is a possible TS, the structure corresponding to this energy point (TS) is further refined with a PBE0/Def2-TZVP theory level until a single imaginary frequency is obtained and the vibrational mode matches the single hydrogen transfer from the methane molecule to the cobalt atom or iron atom in the corresponding cluster.

The same procedure was performed for each $\mathrm{Co}_{n}$ and $\mathrm{Co}_{m} \mathrm{Fe}$ cluster, according to Fig. 7, in any case, the TS is a complex where the hydrogen atom is shared between the cobalt ( $\mathrm{Co}_{n}$ clusters) or iron ( $\mathrm{Co}_{m} \mathrm{Fe}$ clusters) with a $\mathrm{CH}_{3}-\mathrm{H}$ bond distance roughly $1.6 \AA$, largely deviated from the methane

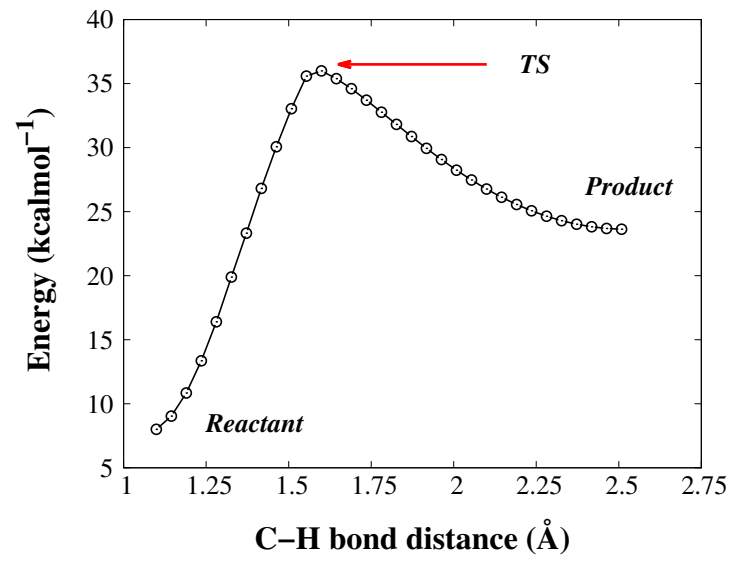

Figure 6. Potential energy surface for the dissociation of $\mathrm{C}-\mathrm{H}$ bond over a single cobalt atom. 


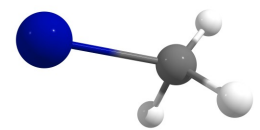

Co-TS

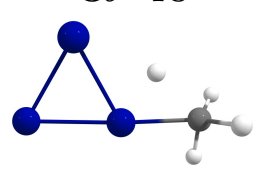

$\mathrm{Co}_{3}-\mathrm{TS}$

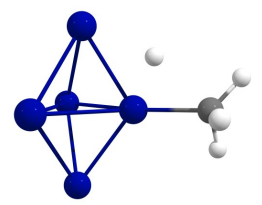

$\mathrm{Co}_{5}-\mathrm{TS}$

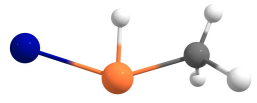

CoFe-TS

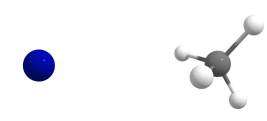

Co-R

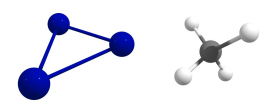

$\mathrm{Co}_{3}-\mathrm{R}$

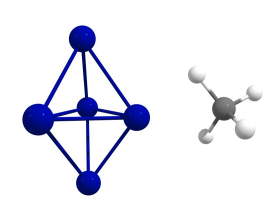

$\mathrm{Co}_{5}-\mathrm{R}$

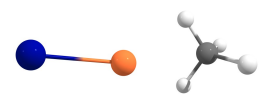

$\mathrm{CoFe}-\mathrm{R}$

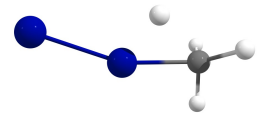

$\mathrm{Co}_{2}-\mathrm{TS}$

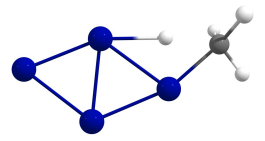

$\mathrm{Co}_{4}-\mathrm{TS}$

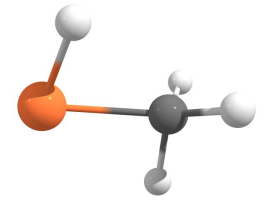

$\mathrm{Fe}-\mathrm{TS}$

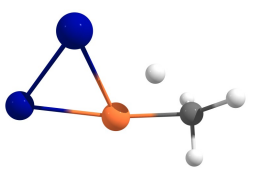

$\mathrm{Co}_{2} \mathrm{Fe}-\mathrm{TS}$

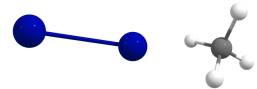

$\mathrm{Co}_{2}-\mathrm{R}$

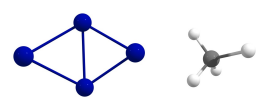

$\mathrm{Co}_{4}-\mathrm{R}$

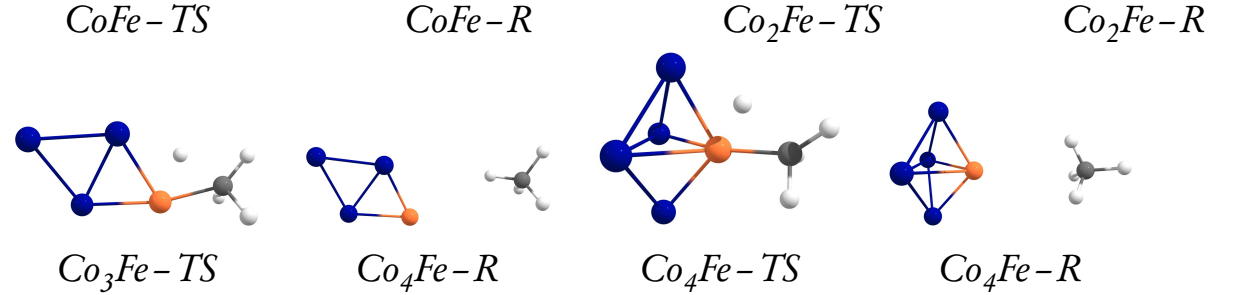

Figure 7. Optimized structures of transition states (TS) and reactants (R) for the $\mathrm{CH}_{4}$ dissociation over $\mathrm{Co}_{m} \mathrm{Fe}(m=0-4)$ and $\mathrm{Co}_{n}(n=1-5)$. Cobalt atoms ; iron atoms $\bigcirc$.

$\mathrm{C}-\mathrm{H}$ bond length $\sim 1.0 \AA$, which is a conclusive evidence of the $\mathrm{CH}_{3}-\mathrm{H}$ hydrogen transfer to the transition metal cluster as reported as the early step in the nanotubes formation [36]. The activation energy is determined as the difference between the Gibbs free energy of the TS and the reactant with thermal correction at $1073 \mathrm{~K}$ (experimental SWCNT growth temperature in this work), see equation (1). According to Fig. 8A, the $\mathrm{AE}$ for $\mathrm{Co}_{n}$ clusters is larger than $90 \mathrm{kJmol}^{-1}$ in all cases while for $\mathrm{Co}_{m} F e$ clusters the $\mathrm{AE}$ is as lower as $33 \mathrm{kJmol}^{-1}$. These findings show less energy requirement for the decomposition of methane over $\mathrm{Co}_{m} \mathrm{Fe}$ clusters, and some computational reports corroborate this trend $[37,38]$ where methane dissociation over cobalt bulk has an AE of the order of $100 \mathrm{kJmol}^{-1}$ while dissociation over iron clusters $\left(\mathrm{Fe}_{4}\right)$ is $45 \mathrm{kJmol}^{-1}$. Since the results in this work for $\mathrm{Co}_{m} \mathrm{Fe}$ clusters are lower than reported, it is possible to suggest that there is some synergistic effect on these iron-cobalt clusters that leads to a lower AE. 
A

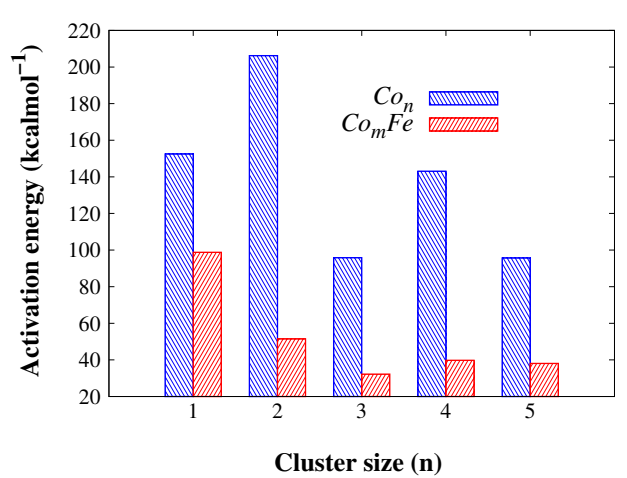

B

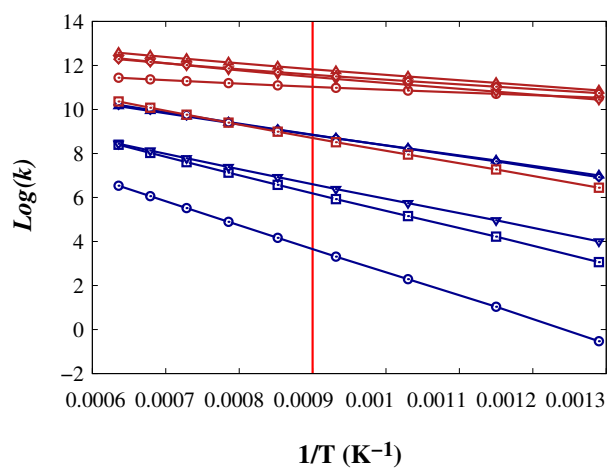

Figure 8. $\mathrm{CH}_{3}-\mathrm{H}-\mathrm{M}(\mathrm{M}=\mathrm{Fe}$ or $\mathrm{Co})$ activation energy (A) and Methane dissociation kinetics, temperature reciprocal tendency over: $\mathrm{Co} \square, \mathrm{Co}_{2} \mathrm{O}, \mathrm{Co}_{3}$ $\triangle, \mathrm{Co}_{4} \nabla, \mathrm{Co}_{5} \diamond, \mathrm{Fe} \square, \mathrm{CoFe} \bigcirc, \mathrm{Co}_{2} \mathrm{Fe} \triangle, \mathrm{Co}_{3} \mathrm{Fe} \nabla, \mathrm{Co}_{4} \mathrm{Fe} \diamond(\mathrm{B})$. The vertical red line marks the actual experimental temperature.

Reaction rate constants were determined in the temperature range $773 \mathrm{~K}-1573 \mathrm{~K}$ using a simplified transition state theory, see equation (2). Fig. $8 \mathrm{~B}$ depicts the relationship between $1 / T$ and $\log (k)$. According to the plot, the dissociation over $\mathrm{Co}_{2}$ shows the slowest rate constant while dissociation over $\mathrm{Co}_{2} \mathrm{Fe}$ the fastest. Dissociation over a single Fe atom occurs nearly at the same speed as over a Co atom which means that a single Fe atom does not have the same activation effect as the iron-containing clusters, thus, a synergistic effect of iron-cobalt is confirmed to be responsible for the speed enhance in the bimetallic cluster that leads to a rate constant ratio up to $1.17 \times 10^{11}$.

A possible explanation for the synergistic effect could be related to the charge over atoms directly involved in the reaction, in the TS equilibrium geometries. Mulliken atomic charges of cobalt atoms in pure cobalt clusters, appearing in Table 3, show a notorious trend to decrease as the cluster size increases, a charge delocalization overall the $\mathrm{Co}_{n}$, while the charge bear by iron and carbon remains almost constant. The charge difference of the atoms in the transition state is an evidence of stabilization, the larger the difference the stronger the electrostatic interaction between both atoms ( $\mathrm{Co}-\mathrm{C}$ or $\mathrm{Fe}-\mathrm{C}$ ). Since the $\mathrm{Fe}-\mathrm{C}$ couple has the larger charge difference the stabilization by electrostatic interaction is expected to be better than the Co-C case, which could lead to a decrease in the activation energy. The first step in the SWCNT growth is the methane molecule dissociation over the transition metal cluster, a rapid carbon uptake (fast dissociation kinetics) could lead to a rapid coverage of the metal particle driving a faster SWCNT growth over the same time for different catalysts with non-equal iron content. 
Table 3. Cobalt, iron and carbon Mulliken atomic charges $(\delta)$ extracted from the optimized structure corresponding to each transition state.

\begin{tabular}{cccccc}
\hline Cluster & $\boldsymbol{\delta}_{\mathrm{Co}}$ & $\boldsymbol{\delta}_{\mathrm{C}}$ & Cluster & $\boldsymbol{\delta}_{\mathrm{Fe}}$ & $\boldsymbol{\delta}_{\mathrm{C}}$ \\
\hline $\mathrm{Co}_{0}$ & 0.153 & -0.529 & $\mathrm{Fe}$ & 0.161 & -0.502 \\
$\mathrm{Co}_{2}$ & 0.113 & -0.592 & $\mathrm{CoFe}$ & 0.176 & -0.586 \\
$\mathrm{Co}_{3}$ & 0.090 & -0.558 & $\mathrm{CoFe}_{2}$ & 0.170 & -0.611 \\
\hline $\mathrm{Co}_{3}$ & 0.055 & -0.576 & $\mathrm{CoFe}_{3}$ & 0.164 & -0.566 \\
$\mathrm{Co}_{5}$ & 0.029 & -0.559 & $\mathrm{CoFe}_{4}$ & 0.139 & -0.545 \\
\hline
\end{tabular}

\section{Conclusions}

Incorporation of cobalt and iron cations was conducted in this work and determined by following the spectral features through DRS-UV spectroscopy showing it is feasible to incorporate both cations without losing the MCM-41 porous features, confirmed by $\mathrm{N}_{2}$-adsorption. The catalytic performance showed a dependency of yield and selectivity with the iron content, leading to well defined graphitic like structures growth over catalysts with a higher iron amount. DFT simulations performed in this work aid to explain the improvement offered by iron, finding, a lower AE for $\mathrm{Co}_{m} \mathrm{Fe}$ clusters than $\mathrm{Co}_{n}$ clusters; also, the transition state is most likely stabilized by electrostatic interactions between the carbon atom and the metal directly attached during the dissociation step.

\section{Acknowledgments}

Frank Ramírez Rodríguez would like to thank Colciencias for the scholarship Francisco José de Caldas, 511.

\section{Conflict of interest}

The authors declare no conflict of interest.

funding

No external funding applies to this study.

\section{References}

[1] MS Dresselhaus, G Dresselhaus, JC Charlier, E Hernandez. Philosophical Transactions of the Royal Society A: Mathematical, Physical and Engineering Sciences, 362(1823): 2065-2098, 2004.

doi: 10.1098/rsta.2004.1430 
[2] Prabhakar R Bandaru. Journal of Nanoscience and Nanotechnology, 7(4): 1239-1267, 2007.

doi: 10.1166/jnn.2007.307

[3] M Cadek, JN Coleman, KP Ryan, V Nicolosi, G Bister, A Fonseca, JB Nagy, K Szostak, F Béguin, WJ Blaut. Nano Letters, 4(2): 353-356, 2004.

doi: 10.1021/NL035009O

[4] Erik T Thostenson, Zhifeng Ren, Tsu-Wei Chou. Composites Science and Technology, 61(13): 1899-1912, 2001.

doi: 10.1016/S0266-3538(01)00094-X

[5] Min-Feng Yu, Bradley S Files, Sivaram Arepalli, Rodney S Ruoff. Physical Review Letters, 84(24): 5552-5555, 2000.

doi: 10.1103/PhysRevLett.84.5552

[6] AR Tameev, L Licea Jiménez, L Ya Pereshivko, RW Rychwalski, AV Vannikov. Journal of Physics: Conference Series, 61(1): 1152$1156,2007$.

doi: $10.1088 / 1742-6596 / 61 / 1 / 228$

[7] Shenqiang Ren, Marco Bernardi, Richard R Lunt, Vladimir Bulovic, Jeffrey C Grossman, Silvija Gradečak. Nano letters,

doi: $10.1021 / \mathrm{nl} 202796 \mathrm{u}$

[8] Tom Grace, LePing Yu, Christopher Gibson, Daniel Tune, Huda Alturaif, Zeid Al Othman, Joseph Shapter. Nanomaterials, 6(3): 52, 2016.

doi: 10.3390/nano6030052

[9] T Du, SA Getty, Enrique Cobas, MS Fuhrer, T Dürkop, SA Getty, Enrique Cobas, MS Fuhrer. Extraordinary Mobility in Semiconducting Carbon Nanotubes. Nano Letters, 4(1): 35-39, 2003.

doi: $10.1021 / \mathrm{nl034841q}$

[10] Rebecca S Park, Gage Hills, Joon Sohn, Subhasish Mitra, Max M. Shulaker, H-S PhilipWong. ACS Nano, 11(5): 4785-4791, 2017.

doi: 10.1021/acsnano.7b01164 
[11] Jing Kong, Alan M Cassell, Hongjie Dai. Chemical Physics Letters, 292(4-6): 567-574, 1998.

doi: 10.1016/S0009-2614(98)00745-3

[12] Li Wei, Shihe Bai, Wenkuan Peng, Yang Yuan, Rongmei Si, Kunli Goh, Rongrong Jiang, Yuan Chen. Carbon, 66: 134-143, 2014.

doi: 10.1016/j.carbon.2013.08.051

[13] D Ciuparu, Y Chen, S Lim, GL Haller, L Pfefferle. Journal of Physical Chemistry B, 108(2): 503-507, 2004.

doi: 10.1021/jp036453i

[14] Bartosz Kruszka, Artur P. Terzyk, L.M. Hoyos-Palacio, Ag García, JF Pérez-Robles, J González, HV Martínez-Tejada. IOP Conference Series: Materials Science and Engineering, 59(1): 012005, 2014.

[15] Yoshikazu Homma, Yoshiro Kobayashi, Toshio Ogino, Daisuke Takagi, Roichi Ito, Yung Joon Yj Yung Joon Jung, Pulickel M Pm Ajayan. The Journal of Physical Chemistry B, 107(44): 12161-12164, 2003.

doi: $10.1021 /$ jp0353845

[16] Codruta Zoican Loebick, Darlington Abanulo, Magda Majewska, Gary L Haller, Lisa D Pfefferle. Effect of reaction temperature in the selective synthesis of single wall carbon nanotubes (SWNT) on a bimetallic CoCr-MCM-41 catalyst. Applied Catalysis A: General, 374(1-2): 213-220, 2010.

doi: 10.1016/j.apcata.2009.12.010

[17] Yiming Li, Woong Kim, Yuegang Zhang, Marco Rolandi, Dunwei Wang, and Hongjie Dai. Growth of single-walled carbon nanotubes from discrete catalytic nanoparticles of various sizes. Journal of Physical Chemistry B, 105(46): 11424-11431, 2001.

doi: 10.1021/jp012085b

[18] László Vanyorek, Danilo Loche, Hajnalka Katona, Maria Francesca Casula, Anna Corrias, Zoltán Kónya, Ákos Kukovecz, Imre Kiricsi. Optimization of the catalytic chemical vapor deposition synthesis of multiwall carbon nanotubes on $\mathrm{FeCo}(\mathrm{Ni}) /$ $\mathrm{SiO}_{2}$ aerogel catalysts by statistical design of experiments. Journal of Physical Chemistry C, 115(13): 5894-5902, 2011.

doi: $10.1021 /$ jp111860x 
[19] Codruta Zoican Loebick, Sungchul Lee, Salim Derrouiche, Mark Schwab, Yuan Chen, Gary L Haller, Lisa Pfefferle. Journal of Catalysis, 271: 358-369, 2010.

doi: $10.1016 /$ j.jcat.2010.02.021

[20] Frank Neese. Wiley Interdisciplinary Reviews: Computational Molecular Science, 2(1): 73-78, 2012.

doi: 10.1002/wcms.81

[21] Ansgar Schäfer, Christian Huber, Reinhart Ahlrichs. The Journal of Chemical Physics, 100(8): 5829-5835, 1994.

doi: $10.1063 / 1.467146$

[22] Cynthia J Jameson, Angel C. de Dios. The Journal of Chemical Physics, 97(1): 417-434, 1992.

doi: $10.1063 / 1.463586$

[23] Carlo Adamo, Vincenzo Barone. Journal of Chemical Physics, 110(13): 6158-6170, 1999.

doi: $10.1063 / 1.478522$

[24] Stephen Brunauer, PH Emmett, Edward Teller. Journal of the American Chemical Society, 60(1): 309-319, 1938.

doi: 10.1021/ja01269a023

[25] Elliott P Barrett, Leslie G Joyner, Paul P Halenda. Journal of the American Chemical Society, 73(1): 373-380, 1951.

doi: 10.1021/ja01145a126

[26] MD Donohue, GL Aranovich. Advances in Colloid and Interface Science, 76-77: 137-152, 1998.

doi: 10.1016/S0001-8686(98)00044-X

[27] Sangyun Lim, Dragos Ciuparu, Chanho Pak, Frank Dobek, Yuan Chen, David Harding, Lisa Pfefferle, Gary Haller. The Journal of Physical Chemistry B, 107(40): 11048-11056, 2003.

doi: $10.1021 / j p 0304778$

[28] XS Zhao, GQ Lu, AK Whittaker, GJ Millar, HY Zhu. Journal of Physical Chemistry B, 101(33): 6525-6531, 1997.

doi: 10.1021/jp971366+ 
[29] L Pfefferle, G Haller, Y Chen, D Ciuparu, S Lim, YH Yang. Abstracts of Papers of the American Chemical Society, 229: 15565$15571,2005$.

doi: 10.1021/jp048067m

[30] Younes Brik, Mohamed Kacimi, Mahfoud Ziyad, François Bozon-Verduraz. Journal of Catalysis, 202(1): 118-128, 2001.

doi: $10.1006 /$ jcat.2001.3262

[31] Ettireddy P Reddy, Bo Sun, Panagiotis G Smirniotis. Journal of Physical Chemistry B, 108(44): 17198-17205, 2004.

doi: 10.1021/JP047419M

[32] Brian J Landi, Cory D Cress, Chris M Evans, Ryne P Raffaelle. Chemistry of Materials, 17(26): 6819-6834, 2005.

doi: $10.1021 / \mathrm{cm} 052002 \mathrm{u}$

[33] RA Jishi, L Venkataraman, MS Dresselhaus, G Dresselhaus. Chemical Physics Letters, 209(1-2): 77-82, 1993.

doi: 10.1016/0009-2614(93)87205-H

[34] G Dresselhaus A Jorio, MA Pimenta, AG Souza Filho, R Saito, MS Dresselhaus. New journal of Pbysics, 5(1):1-11, 2012.

doi: $10.1088 / 1367-2630 / 5 / 1 / 139$

[35] IT Ghampson, C Newman, L Kong, E Pier, KD Hurley, RA Pollock, BR Walsh, B Goundie, J Wright, MC Wheeler, RW Meulenberg, WJ Desisto. Applied Catalysis A, General, 388(1-2): 57-67, 2010.

doi: 10.1016/j.apcata.2010.08.028

[36] Jingde Li, Eric Croiset, Luis Ricardez-Sandoval. Effects of metal elements in catalytic growth of carbon nanotubes/ graphene: A first principles DFT study. Applied Surface Science, 317: 923-928, 2014.

doi: 10.1016/j.apsusc.2014.09.008

[37] Xiaobin Hao, Qiang Wang, Debao Li, Riguang Zhang, Baojun Wang. RSC Adv., 4(81): 43004-43011, 2014.

doi: 10.1039/C4RA04050C 
[38] Qiao Sun, Zhen Li, MengWang, Aijun Du, Sean C Smith. Chemical Physics Letters, 550: 41-46, 2012.

doi: 10.1016/j.cplett.2012.08.057

Crecimiento de nanotubos de carbono de pared simple sobre catalizador bimetálico mesoporoso MCM-41 de cobalto-hierro bajo deposición química de vapor de metano, una evaluación experimental y por DFT

Resumen: Catalizadores de cobalto y hierro MCM-41 fueron sintetizados a través de un proceso de incorporación in-situ a partir de nitratos comerciales de hierro y cobalto. La incorporación se confirmó mediante espectroscopía UV de reflectancia difusa (DRS-UV) inspeccionando las características tipo-silicato de la absorción fotónica de cobalto y hierro, y comparando con catalizadores MCM-41-Co y MCM-41-Fe puros. Además se encon tró que la incorporación de cobalto y de hierro no compromete la estructura mesoporosa de MCM-41 como lo confirman las isotermas de adsorción de $\mathrm{N}_{2}$. Todos los catalizadores mostraron amplias áreas de superficie $\left(\sim 1100 \mathrm{~m}^{2} \mathrm{~g}^{-1}\right)$. El rendimiento de los catalizadores se realizó en una deposición química simple de vapor de metano (CVD) preparada a $800{ }^{\circ} \mathrm{C}$ para producir nanotubos de carbono de pared simple (SWCNT) bajo un flujo constante de metano durante 30 minutos. Los productos de CVD se caracterizaron por medio de un análisis termogravimétrico (TGA) y por espectroscopía Raman, encontrando que el contenido de hierro en los catalizadores favorece la selectividad y producción de estructuras de tipo grafítico, y confirmando la presencia de SWCNT por la aparición de modos de respiración radial (RBM) característicos. Estos resultados fueron respaldados por simulaciones con Teoría Funcional de Densidad (DFT) de la disociación de metano $\left(\mathrm{CH}_{4}+\mathrm{TM} \rightarrow \mathrm{H}_{3} \mathrm{C}-\mathrm{TMH}\right)$ sobre Con $(n=1-5)$ y $\mathrm{Co}_{m} \mathrm{Fe}(m=1-4)$, encontrando una tendencia de energía de activación diferente donde los clústeres $\mathrm{Co}_{m} \mathrm{Fe}(m=1-4)$ tienen la energía de activación más baja. El estudio DFT también reveló una diferencia de carga $(\delta \mathrm{C}-\delta \mathrm{TM})$ mayor en el caso de disociación sobre $\mathrm{Co}_{m} \mathrm{Fe}(m=1-4)$ que puede conducir a una estabilización electrostática del metal de transición, disminuyendo la energía de activación de esos clústeres y llevando a una absorción de carbono más rápida.

Palabras clave: DFT; Raman; SWCNT; UV-Vis. 


\section{Crescimento de nanotubos de carbono de parede única sobre catalisador bimetálico mesoporoso de ferro-cobalto MCM-41 sob deposiçáo de vapor químico de metano, uma avaliaçáo experimental e por DFT}

Resumo: Catalisadores de cobalto e ferro MCM-41 foram sintetizados através de um processo de incorporação in situ a partir de nitratos comerciais de ferro e cobalto. A incorporação foi confirmada por espectroscopia UV de refletância difusa (DRS-UV), inspecionando as características do tipo silicato da absorção fotônica de cobalto e ferro e comparando com catalisadores MCM-41-Co e MCM-41-Fe puros. Além disso, verificou-se que a incorporação de cobalto e ferro não compromete a estrutura mesoporosa do MCM-41, conforme confirmado pelas isotermas de adsorção de $\mathrm{N}_{2}$. Todos os catalisadores mostraram amplas áreas de superfície ( $1100 \mathrm{~m} 2 \mathrm{~g}-1)$. O desempenho dos catalisadores foi realizado em uma deposição química simple de vapor de metano (CVD) preparada a $800^{\circ} \mathrm{C}$ para produzir nanotubos de carbono de parede única (SWCNT) sob um fluxo constante de metano por 30 minutos. Os produtos CVD foram caracterizados por meio de uma análise termogravimétrica (TGA) e por espectroscopia Raman, constatando que o teor de ferro nos catalisadores favorece a seletividade e a produção de estruturas semelhantes a grafite e confirma a presença de SWCNT pelo aparecimento de modos característicos de respiração radial (RBM). Esses resultados foram apoiados por simulações com a Teoria da Densidade Funcional (DFT) da dissociação de metano $\left(\mathrm{CH}_{4}+\mathrm{TM} \rightarrow \mathrm{H}_{3} \mathrm{C}-\mathrm{TMH}\right)$ em $\mathrm{Con}(n=1-5)$ e $\mathrm{Co}_{m} \mathrm{Fe}(m=1-4)$, encontrando um tendência de energia de ativação diferente, onde os clusters $\mathrm{Co}_{m} \mathrm{Fe}(m=1-4)$ têm a menor energia de ativação. $\mathrm{O}$ estudo DFT também revelou uma maior diferença de carga $(\delta C-\delta \mathrm{TM})$ no caso de dissociação em $\mathrm{Co}_{m} \mathrm{Fe}(m=1-4)$ que pode levar a uma estabilização eletrostática do metal de transição, diminuindo a energia de ativação desses clusters e levando a uma absorção de carbono mais rápida.

Palavras-chave: DFT; Raman; SWCNT; UV-Vis. 


\section{Frank Ramírez Rodríguez}

Chemist from the University of Antioquia and Ph.D. in chemistry, Postdoctoral fellow in quantum mechanic simulation of $\pi$-conjugated small molecules with potential use in optoelectronics. Professor at the Universty of Antioquia since 2016.

ORCID: 0000-0002-9520-2910

\section{Betty Lucy López Osorio}

Chemical engineer from the University of Antioquia, M.Sc in chemistry from the Lehigh University, Ph.D. in chemistry from the University of North Texas. Associated professor at the University of Antioquia since 1972, founded the Polimers grupo in 1996 which turned in the Science of Materials Research Group (CIENMATE, in Spanish) in 1998.

ORCID: 0000-0002-5564-9531 